\title{
ANALISIS FUNGSI DISTRIBUSI KEUANGAN NEGARA (Studi Pemikiran 'Abdul Qadim Zallum)
}

\author{
Nunung Nurlaela \\ Dosen STEI Hamfara Yogyakarta \\ Email: ummunawazim@gmail.com
}

\section{Abstract}

Indonesian budget deficit from year to year, and the other hand haven't been able to improve the life of people with evenly and the economic assets aren't placed on proper tipping point, so we need a new way. This study presents an alternative formulation of the budget options with a focus on the distribution function, use qualitative method with a phenomenological approach and using descriptive analysis. The emphasis of this study is the distribution function of the state budget that was initiated by Shaikh Abdul Qadim Zallum and their application with a case study in 2010-2012 Indonesian budget. The result is the state will be able to flatten the welfare of people at once to function, rolling the industrialization process, without deficit. Economic stability will be a real foundation for economic growth. The development program based on Islamic political economy requires bureaucracy reform to cut many programs that are not targeted. So, this concept was initiated by Sheikh Abdul Qadeem Zallum be considered to solve the Indonesian budgeting problems.

\section{تجريد}

إن الميزانية الإندونيسية تقع في العجز من سنة إلى أخرى. وفي وجه آخر، لم تقدر على تحسين حياة الناس تساويا، وليست الأصول الاقتصادية بموضع نقطة التحول المناسبة. فلذلك، نحتاج إلى الطريقة الجحيدة. وهذه الدراسة تقدم صيغة بديلة من خيارات الميزانية مع التركيز على وظيفة التوزيع، وتستخدم طريقة النوعي مع مقاربة الظواهر واستخدام التحليل الوصفي. وكان التركيز في هذه الدراسة هو وظيفة توزيع الميزانية الدولية التي بدأتها الشيخ عبد القديم زلوم وتطبيقها مع دراسة حالة في الفترة 


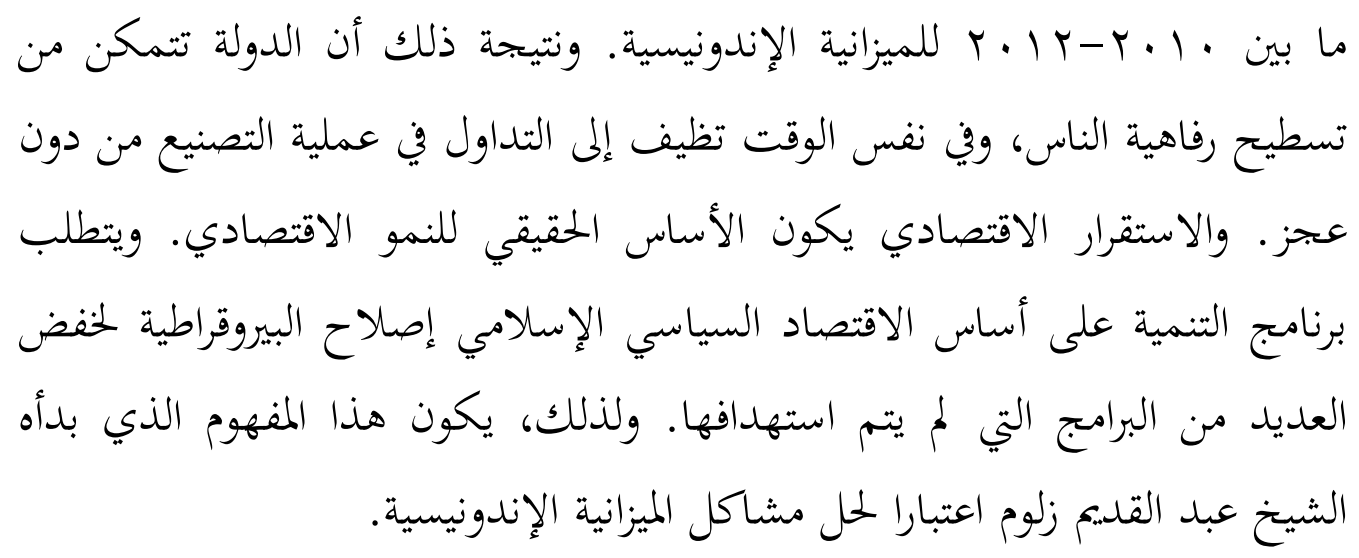

Keywords: Anggaran, defisit, fungsi distribusi, keuangan, kesejahteraan ssosial.

\section{A. Pendahuluan}

Pelaku ekonomi yang sangat berpengaruh terhadap masyarakat adalah negara. Hal ini karena kemampuannya dalam mengarahkan pola interaksi ekonomi pelaku ekonomi lainnya serta adanya kemampuan untuk memaksa pihak lain untuk melakukan suatu tindakan ekonomi. Peran pemerintah dalam perekonomian ini sebagian besar merupakan konsekuensi dari semakin kompleks dan saling ketergantungan di dalam masyarakat modern. ${ }^{1}$ Jadi, Anggaran Penerimaan dan Belanja Negara (APBN) mempunyai pengaruh yang sangat besar terhadap kesejahteraan rakyat, khususnya melalui fungsi distribusinya baik terkait dengan pemasukan maupun pengeluarannya,

Fakta menunjukkan bahwa jumlah anggaran baik penerimaan APBN Indonesia maupun pengeluarannya meningkat setiap tahunnya, namun demikian tidak tampak dampaknya terhadap kesejahteraan rakyat secara signifikan. Hal ini bisa terjadi karena kebijakan ekonomi yang diterapkan di Indonesia hanya difokuskan pada penyediaan alat yang memuaskan kebutuhan masyarakat secara makro dengan cara menaikkan tingkat produksi dan meningkatkan pendapatan nasional, bukan dengan pandangan untuk

1 Yuswar Zainul basri dan Mulyadi Subri, Keuangan Negara dan Analisis Kebijakan Utang Luar Negeri, (Jakarta: Rajagrafindo Persada, 2003), hal. 11. 
memuaskan kebutuhan setiap individu. ${ }^{2}$ Indikasi kebijakan tersebut bisa dilihat dari aspek penerimaan maupun pengeluaran APBN.

Fakta kedua yang perlu dicermati pada APBN Indonesia adalah kecenderungannya untuk tetap mengalami defisit dari tahun ke tahun. Penting untuk dicermati adalah solusi yang diambil pemerintah untuk menutupi defisit APBN tersebut, yaitu melalui pencabutan/pengurangan subsidi, menaikkan pajak, serta melalui utang baik dari dalam maupun luar negeri.

APBN suatu negra dikatakan sehat jika mengalami surplus yang dengannya masyarakat kemudian bisa bertolak ke tingkat kemakmuran yang lebih tinggi atau minimal seimbang antara penerimaan dan belanjanya. APBN yang mengalami defisit dari tahun ke tahun sebenarnya menunjukkan bahwa fondasi ekonomi negara tersebut tidak kuat, dan jika hal ini secara langsung terus menerus akan berpengaruh terhadap aspek-aspek yang lain, seperti kestabilan internal dalam negeri, kekuatan militer, pengaruh politik luar negeri, dan lainlain.

Melihat fenomena APBN yang terus mengalami defisit, maka perlu diteliti lebih jauh tentang akar masalah atau penyebabnya, sekaligus dampaknya terhadap APBN pada tahun-ahun mendatang. Hal ini karena paradigma APBN berhubungan erat dengan politik ekonomi yang dipilih oleh negara. Oleh karena itu penting untuk melakukan evaluasi menyeluruh terhadap penerapan Sistem Ekonomi yang diterapkan di Indonesia, termasuk didalamnya adalah sistem keuangan negara, yang akan menyorot tajam pada aspek pendapatan dan pengeluaran negara.

Indonesia melalui beberapa ahli ekonominya, yang dimotori oleh Prof. Mubyarto telah mengembangkan sistem ekonomi yang khas sesuai dengan karakteristik bangsa (Sistem Ekonomi Indonesia), sebagai bentuk ketidakpuasan atas fakta ekonomi di Indonesia, yang diberi nama Ekonomi Pancasila. Ekonomi khas Indonesia ini dikembangkan berdasar kehidupan ekonomi riil rakyat Indonesia. ${ }^{3}$ Upaya membangun wacana yang revolusioner tersebut ternyata tidak disambut oleh sebagian besar ahli ekonomi Indonesia, yang justru lebih condong pada kapitalisme-liberalisme. Gerakan yang pernah menjadi isu utama

Yulianto, “APBN Anti Rakyat”, al-Wa'ie, No. 122 Th. Ke XI (Oktober 2010), hal. 9.

3 Edy Suandi Hamid, Ekonomi Indonesia, dari Sentralisasi ke Desentralisasi, (Yogyakarta: UII Press, 2006), hal. 27. 
di Indonesia, yaitu pada era1980-an, kemudian hilang, disebabkan karena seakan Prof. Mubyarto berjalan sendirian dan hanya ditemani mitra yang terbatas. ${ }^{4}$ Inilah yang terjadi pada perjuangan intelektual, ketika tidak ditransformasikan menjadi gerakan politik, daya gebraknya tidak akan cukup kuat menghantam sistem jika bergerak di luar sistem, yang disebabkan penolakan dari lingkaran dalam pimpinan pusat.

Satu hal yang kemudian juga perlu menjadi perhatian adalah tumbuh berkembangnya wacana ekonomi Islam. Wacana ekonomi Islam ini dibangun dan digali, untuk ikut andil dalam menyelesaikan masalah-masalah ekonomi. Terdapat wacana yang diusung secara ilmiah atau gerakan intelektual namun ada juga wacana yang diusung oleh gerakan politik. Penting untuk mencermati pemikiran-pemikiran yang dibawa oleh gerakan-gerakan politik yang berbasis pada pemikiran, karena adanya upaya penerapan secara nyata dalam kehidupan bernegara, yaitu melalui aktivitas politik.

Salah satu wacana tentang Sistem Ekonomi Islam adalah pembahasan keuangan negara dalam Islam digagas oleh Syaikh 'Abdul Qadim Zallum dalam kitab al-Amwal fi ad-Daulah al-Khilafah. Kitab al-Amwal fi ad-Daulah alKhilafah tersebut adalah penjabaran khusus dari kitab an-Nizam al-Iqtișadi fi alIslam (Sistem Ekonomi di dalam Islam) karya Syaikh Taqiyyudin an-Nabhani ${ }^{5}$ pada bidang keuangan negara.

\section{B. Struktur Pendapatan dan Belanja Negara menurut Syaikh 'Abdul Qadim Zallum}

Persoalan utama yang harus dijawab oleh setiap sistem ekonomi ada tiga, yaitu: (1) barang dan jasa apa yang akan dihasilkan dan berapa jumlahnya, (2) bagaimana pola atau cara memproduksinya, dan (3) untuk siapa barang tersebut dihasilkan serta bagaimana pola distribusinya ke masyarakat. ${ }^{6}$ Berdasarkan ketiga persoalan utama tersebut, yang bisa disingkat dengan masalah produksi,

\footnotetext{
4 Edy Suandi Hamid, Sistem Ekonomi, Utang Luar Negeri, dan Isu-isu Ekonomi Politik Indonesia, (Yogyakarta: UII Press, 2004), hal. 50.

5 Syaikh Taqiyuddin an-Nabhani merupakan pendiri sekaligus Amir Hizbut Tahrir yang pertama. M.'Ali Dodiman, Memoar Pejuang Syariah dan Khilafah (Biografi Ringkas Tokoh Senior Hizbut Tahrir), (Bogor: Al Azhar Freshzone Publishing, 2012), hal.62.

6 Edy Suandi Hamid, Sistem Ekonomi, Utang Luar Negeri, dan Isu-isu Ekonomi Politik Indonesia, (Yogyakarta: UII Press, 2004), hal. 36.
} 
konsumsi, dan distribusi, sesungguhnya masalah distribusi adalah masalah yang paling mendasar (hakiki). ${ }^{7}$ Berbeda dengan dua persoalan yang lain, ternyata akal manusia tidak akan pernah dapat memecahkan masalah distribusi secara adil. Maka, manusia perlu petunjuk dari Allah SWT mengenai masalah distribusi ini, agar terciptanya distribusi yang adil di tengah-tengah manusia.

Syaikh 'Abdul Qadim Zallum memulai menyusun pandangannya bertolak dari pandangan bahwa sistem kenegaraan Islam memiliki format yang berbeda, jika dibandingkan dengan sistem kenegaraan lainnya, baik dari aspek asas negara, struktur, maupun konstitusinya. Hal ini mengharuskan negara Islam menyelenggarakan pemeliharaan seluruh urusan umat dan melaksanakan aspek administratif terhadap harta yang masuk ke negara, termasuk cara penggunaannya, sehingga memungkinkan bagi negara untuk memelihara urusan umat dan mengemban dakwah. Hal ini karena dalil-dalil syara' telah menjelaskan sumber-sumber pendapatan harta negara, jenis-jenisnya, cara perolehannya, pihak-pihak yang berhak menerimanya, serta pos-pos pembelanjaannya. $^{8}$

Keuangan Negara dalam Islam yang dimaksud oleh Syaikh 'Abdul Qadim Zallum merupakan konsep keuangan negara Khilafah. Tujuan yang ingin diwujudkan, konsep, metode, dan format penyusunannya berdasar pada konsep negara Khilafah. Prinsip-prinsip utama sistem keuangan negara Khilafah menurut Syaikh 'Abdul Qadim Zallum adalah sebagai berikut: (1) Baitul Mal merupakan APBN, (2) Pemasukan dan pengeluaran negara berdasar pada hukum syara' (3) Pengelolaan keuangan negara merupakan wewenang Khalifah, dan (4) Struktur APBN Khilafah, terdiri atas dua pos yaitu pos pemasukan dan pos pengeluaran negara.

\section{Pos Pemasukan Negara}

Pendapatan Negara terdiri atas tiga pos, yaitu: (a) pos fa'i dan kharaj, (b) pos kepemilikan umum, dan (c) pos zakat. Setiap pos ditangani oleh badan (dewan) tersendiri, yaitu (1) Bagian Fa'i dan Kharaj, (2) Bagian kepemilikan Umum,

7 Dwi Condro Triono, Ekonomi Islam Madzhab Hamfara, Jilid I, (Yogyakarta: Irtikaz, 2011), hal. 224.

8 Abdul Qadim Zallum, Sistem Keuangan di Negara Khilafah (al-Amwaal fii Daulah alKhilafah), alih bahasa oleh Ahmad S, (Bogor: Pustaka Thariqul Izzah, 2002), hal. 2. 
dan (3) Bagian Shadaqah. Badan tersebut bertanggung jawab terkait dengan penyimpanan sekaligus catatan-catatan administratifnya. Bagian kepemilikan umum mempunyai tugas tambahan yaitu melakukan analisis, mencari, mengambil, dan memasarkan harta kepemilikan umum tersebut. Ketiga pos tersebut dibuat terpisah, tidak boleh tercampur satu dengan yang lainnya.

Bagian $F a^{\prime} i$ dan Kharaj dalam pelaksanaannya terdiri atas enam urusan, yaitu (a) urusan Ganimah, yang mencakup ganimah, anfal, fa'i, dan khumus; (b) urusan kharaj; (c) urusan status tanah yang bertugas administratif terkait tanahtanah di seluruh wilayah negara, baik tanah 'usyriyah, tanah yang ditaklukkan secara paksa, aș-Ṣawafi, tanah-tanah milik negara, tanah-tanah milik umum, dan tanah-tanah yang dikuasai negara; (d) urusan jizyah; (e) urusan fa'i yang mengelola harta dari 'usyur, aș-Sawafi, seperlima harta rikaz, seperlima dari tambang yang kecil, pemasukan dari penjualan dan penyewaan tanah negara, dan harta waris yang tidak ada pewarisnya; dan (f) urusan pajak (daribah). ${ }^{9}$

Bagian pemilikan umum mengelola pemasukan negara dari kepemilikan umum. Bagian ini terdiri atas enam urusan, yaitu: (a) urusan minyak dan gas; (b) urusan listrik; (c) urusan pertambangan; (d) urusan laut, sungai, perairan, dan mata air; (e) urusan hutan dan padang rumput; (f) urusan tempat khusus yang dikuasai negara. ${ }^{10}$ Bagian Shadaqah mencakup pengelolaan pemasukan harta-harta zakat. Bagian ini terdiri atas tiga urusan, yaitu: (a) urusan zakat mal (harta) dan perdagangan; (b) urusan zakat pertanian dan buah-buahan; dan (c) urusan zakat ternak. ${ }^{11}$

\section{Pos Pengeluaran Negara}

Negara sebagai subjek ekonomi berbeda dengan subjek ekonomi lain, seperti perusahaan maupun rumah tangga, yaitu pengeluaran negara yang mempengaruhi penerimaan negara. Hal ini karena negara atau pemerintah mengutamakan kesejahteraan warganya secara keseluruhan. Negara harus dapat menjamin kebutuhan minimum warganya secara keseluruhan. ${ }^{12}$

\footnotetext{
$9 \quad$ Ibid., hal. 13-14.

10 Ibid.

11 Ibid.

12 Suparmoko, Keuangan Negara dalam Teori dan Praktek, edisi V (Yogyakarta: BPFE, 2003), hal. 2.
} 
Pos pengeluaran Negara terdiri atas delapan pos, yaitu: (a) pos dar alkhilafah, (b) pos mașāith ad-daulah, (c) pos santunan, (d) pos jihad, (e) pos penyimpanan harta zakat, (f) pos penyimpanan harta kepemilikan umum, (g) pos urusan darurat/bencana alam, dan (h) pos anggaran belanja negara. Bagian Dar al-Khilafah mengatur belanja negara yang terkait dengan pusat negara, baik Khalifah dan para pembantunya. Bagian ini terdiri atas empat urusan, yaitu: (a) urusan kantor Khilafah; (b) urusan kantor penasehat (mutasyārin); (c) urusan kantor Mua'win at-Tafwid; dan (d) urusan kantor Mu'awin at-Tanfiz.

Bagian kedua adalah Mașālih ad-Daulah yang merupakan bagian paling kompleks, karena mencakup banyak urusan, yang dikelompokkan menjadi empat urusan, yaitu: (a) urusan Amiral-Jihad; (b) urusan penguasa wilayah (wali/ gubernur) ${ }^{13}$; (c) urusan peradilan; dan (d) urusan Mașālih ad-Daulah. Bagian kedua ini mencakup pembiayaan untuk Departemen Perang dan pemerintah daerah, baik wali (gubernur) maupun 'amil (bupati). Urusan mașāih ad-Daulah ini mencakup semua pengeluaran negara yang terkait dengan kemaslahatan umum, seperti Departemen Pendidikan, Departemen Kesehatan, Departemen Keamanan Dalam Negeri, Departemen Pertanian, Departemen Transportasi, dan lain-lain. ${ }^{14}$

Bagian Jihad terdiri atas tiga urusan, yaitu: (a) urusan pasukan, yang mengelola pembentukan dan pelatihan pasukan; (b) urusan persenjataan dan amunisi; dan (c) urusan industri militer. ${ }^{15}$ Perbedaan bagian jihad dengan urusan Amir al-Jihad adalah, pada bagian Jihad ini fokusnya adalah pembiayaan untuk operasi militer, sedangkan administrasi dan gaji tentara dianggarkan pada pos urusan Departemen Perang.

Baitul Mal dalam pelaksanaannya membentuk cabang di setiap wilayah (propinsi). Hal ini untuk memudahkan pengelolaan baitul mal, baik terkait pendapatan maupun belanja negara, sekalipun pengelolaan keuangan bersifat sentralisasi, seperti halnya peradilan dan militer. ${ }^{16}$ Unit-unit yang dibentuk di setiap cabang, disesuaikan dengan kebutuhan, sehingga struktur di setiap wilayah bisa berbeda-beda. ${ }^{17}$

\footnotetext{
13 Urusan para wali ini seperti transfer dari pusat ke daerah dalam APBN Indonesia.

14 Hizbut Tahrir, Struktur., hal 217.

15 Abdul Qadim Zallum, al-Amwal., hal. 17.

16 Hizbut Tahrir, Struktur., hal. 225.

17 Ibid., hal. 221.
} 


\section{Fungsi Distribusi Pendapatan dan Belanja Negara menurut Syaikh 'Abdul Qadim Zallum}

Fokus distribusi Pendapatan dan Belanja Negara menurut Syaikh 'Abdul Qadim Zallum terkait dengan politik ekonomi negara. Prinsip dasarnya adalah khilafah harus menjamin kebutuhan pokok rakyat, sebagai individu per individu dan bukan melihat kebutuhan masyarakat keseluruhan, serta memberikan kesempatan seluas-luasnya kepada warga negara untuk memenuhi kebutuhan sekunder dan tersiernya. Kebutuhan pokok rakyat meliputi kebutuhan personal yaitu pangan, pakaian, dan tempat tinggal, serta kebutuhan yang sifatnya komunal, yaitu keamanan, kesehatan, dan pendidikan. Inilah perbedaan dasar antara sistem ekonomi Islam dengan sistem kapitalisme dan sosialisme komunisme. ${ }^{18}$

Negara mendistribusikan pendapatan negara kepada rakyat (muslim dan non muslim) melalui beberapa mekanisme: (1) kebutuhan komunal (keamanan, pendidikan, kesehatan, dan sarana/prasarana umum) akan dipenuhi oleh negara kepada rakyat tanpa memandang muslim maupun non muslim, (2) negara melalui bank negara (salah satu unit/jawatan di Baitul Mal) akan memberikan pinjaman tanpa riba atau bahkan pemberian secara cuma-cuma kepada rakyat dengan mekanisme tertentu untuk membuka atau mengembangkan usaha, (3) negara membuka lapangan kerja baru, melalui pembukaan industri-industri yang diperlukan, menghidupkan tanah mati, dan lain sebagainya. Hal ini untuk mempercepat pertumbuhan ekonomi sehingga mampu meningkatkan standar hidup sampai pada tingkat yang layak bahkan lebih dari itu, dan (4) negara memberikan santunan (tunjangan sosial) kepada muslim maupun Aḥlu ȧ்-Żimmah, serta mendistribusikan harta zakat kepada pihak-pihak yang membutuhkan, untuk mencukupi kebutuhan personalnya seperti pangan, sandang, dan tempat tinggal, atau bisa juga dimanfaatkan untuk sektor produktif.

Khalifah dalam menetapkan pos-pos pembelanjaan negara, setidaknya harus mengikuti enam kaidah utama dalam pengalokasian anggaran belanjanya

18 Kapitalisme membebaskan kepemilikan dan setiap individu berjuang untuk mendapatkannya, sedangkan sistem sosialisme-komunisme membatasi kepemilikan dan membaginya kepada rakyat dengan cara tertentu. Islam menjamin kebutuhan pokok rakyat namun memberikan kebebasan untuk memenuhi kebutuhan sekunder dan tersiernya. 
19, yaitu:

1. Khusus untuk harta Baitul Mal yang berasal dari zakat, maka pos pengelurannya wajib hanya untuk yang berhak saja, yaitu 8 golongan yang disebutkan dalam surat at-Taubah (9): $60 .^{20}$

2. Pos pembelanjaan wajib dan bersifat tetap dari Baitul Mal untuk keperluan jihad dan menutup kebutuhan orang-orang fakir dan miskin.

3. Pos pembelanjaan wajib dan bersifat tetap dari Baitul Mal untuk memberikan gaji atau jasa yang telah dicurahkan untuk kepentingan Negara, yaitu pegawai negeri, hakim, tentara dan sebagainya.

4. Pos pembelanjaan untuk pembangunan sarana kemaslahatan rakyat yang bersifat wajib, yaitu jika sarana itu tidak ada, maka akan menimbulkan kemudharatan bagi rakyat, seperti pembangunan jalan, jembatan, sekolah, rumah sakit, masjid, penyediaan air bersih dan sebagainya.

5. Pos pembelanjaan wajib yang bersifat kondisional, yaitu untuk menanggulangi terjadinya musibah atau bencana alam yang menimpa rakyat, seperti gempa bumi, musim paceklik, banjir, dan sebagainya.

6. Pos pembelanjaan untuk pembangunan sarana kemaslahatan rakyat yang bersifat tidak wajib, yaitu sarana tersebut hanya bersifat penambahan dari sarana-sarana yang sudah ada dan jika sarana tersebut tidak ada, tidak menimbulkan kemudharatan bagi rakyat.

Seorang khalifah mempunyai tata cara dalam mengatur pengeluaran sekaligus tata cara untuk menutupi kekurangan anggaran, karena kas Baitul Mal bersifat tidak tetap. Tergantung besar kecilnya pemasukan sumber-sumber pendapatan dari Baitul Mal, serta tidak mengacu pada anggaran tahunan sekalipun ada perencanaan anggaran. Adapun tata caranya, dikembalikan pada jenis-jenis dari pos pengeluarannya. Penjelasannya adalah sebagai berikut: (1) pos pengeluaran jenis pertama, maka pengeluaran yang harus dilakukan oleh Khalifah hanya berdasarkan pada banyaknya zakat yang masuk ke kas Baitul Mal, kemudian disalurkan kepada 8 golongan, sebagaimana yang telah ditentukan oleh Al-Quran. Jika harta dari zakat itu tidak ada lagi dalam Baitul Mal

19 Taqiyuddin an-Nabhani, Membangun., hal. 264-267.

20 QS. at-Taubah (9): 60, Sesungguhnya zakat itu hanya untuk orang-orang fakir, orangorang miskin, para 'amilin (zakat), muallaf, budak, orang-orang berhutang, jihad fi sabilillah, dan ibnu sabil. 
atau harta zakatnya sudah habis, maka Khalifah tidak perlu mencari pinjaman untuk membayar zakat bagi rakyatnya; (2) Pos pengeluaran dari jenis kedua jenis yang kelima, maka khalifah harus mengeluarkan harta dari kas baitul mal sebagai kewajiban yang harus segera ditunaikan oleh Negara terhadap hakhak yang harus diterima oleh rakyat sesuai dengan kondisi masing-masing. Jika kas Baitul Mal mempunyai kekurangan, maka harus dilihat lebih lanjut. Jika pemenuhan kekurangan itu tidak segera diberikan dapat menyebabkan kemudaratan yang serius, maka khalifah harus segera mengupayakan untuk menutupi kekurangan tersebut. Jika pemenuhan kekurangan tersebut tidak akan menimbulkan kemudharatan yang serius, maka pemenuhan kekurangan tersebut dapat ditunda sampai adanya pemasukan harta lagi; (3) Pengeluaran jenis ke-enam, maka pengeluarannya harus mendasar pada ketersediaan kas Baitul Mal, tergantung ada tidaknya kelebihan dana.

Ekonomi Islam memecahkan masalah distribusi dengan dua pendekatan, yaitu distribusi antar individu dan distribusi melalui negara. ${ }^{21}$ Distribusi antar individu ini dibagi lagi menjadi dua bagian, yaitu distribusi secara ekonomis dan non ekonomis. Distribusi secara ekonomis, yaitu terjadinya proses distribusi antar individu mengikuti mekanisme pasar syari'ah. Pasar syariah adalah semua transaksi antar individu yang berkaitan dengan barang dan jasa dilakukan di pasar tersebut adalah dengan cara-cara yang mengikuti aturan syariat Islam. Jika distribusi secara ekonomis berasal dari adanya motif ekonomi, maka distribusi antar individu secara non ekonomis terjadi karena adanya dorongan untuk mendapat pahala dari Allah SWT. Praktek atau amaliyah dari distibusi tersebut terjadi melalui zakat, nafkah, shadaqoh, hadiah, hibah dan sebagainya. Distribusi antar individu non ekonomis ini bertujuan hanya memperoleh ridho atau pahala dari Allah. Pola distribusi ini tidak ditemukan dalam sistem ekonomi manapun selain Islam. Inilah keunggulan khusus yang ada dalam sistem ekonomi Islam. Distribusi harta kekayaan oleh negara adalah adanya peran negara baik secara langsung maupun tidak langsung dalam pendistribusiannya, inilah yang dikenal sebagai kebijakan fiskal dalam ekonomi kapitalis.

$21 \quad$ Ibid., hal 391-392. 
Penyusunan anggaran belanja negara dalam sistem ekonomi kapitalisme dituangkan dalam nota APBN, sedangkan dalam sistem ekonomi Islam kebijakan dalam pengelolaan anggaran Negara dikelola oleh lembaga Baitul Mal. Pengelolaan APBN oleh Baitul Mal ini perlu dikomparasikan dengan APBN Indonesia.

\section{Struktur APBN Indonesia}

Struktur APBN umumnya terdiri atas dua bagian, yaitu Sumber Penerimaan dan Belanja Negara. APBN Indonesia mengembangkannya dengan memisahkan satu bagian khusus yang disebut dengan pembiayaan, sehingga APBN Indonesia terdiri atas tiga bagian, yaitu: (a) sumber penerimaan, (b) belanja negara, dan (c) pembiayaan. Penjelasannya adalah sebagai berikut:

\section{Sumber Penerimaan APBN}

Penerimaan APBN diperoleh dari berbagai sumber yaitu: Penerimaan Dalam Negeri dan Penerimaan Hibah. Penerimaan Dalam Negeri terdiri atas Penerimaan perpajakan dan Penerimaan Negara Bukan pajak, sedangkan Penerimaan Hibah berasal dari masyarakat, baik dari perorangan, kelompok, organisasi, atau perusahaan, yang berasal dari dalam negeri, negara sahabat, maupun masyarakat internasional.

Pajak adalah suatu pungutan yang dilakukan pemerintah (pusat/daerah) terhadap Wajib Pajak tertentu berdasarkan undang-undang (yang dapat dipaksakan) tanpa harus memberikan imbalan langsung. Penerimaan Negara yang kedua adalah Penerimaan Negara Bukan Pajak (PNBP), yang meliputi: (1) penerimaan dari sumber daya alam; (2) bagian laba dari BUMN; (3) PNBP lainya yaitu: (a) retribusi, (b) denda dan sita, (c) pencetakan uang; dan (4) pendapatan dari badan Layanan Umum (BLU). Khusus untuk pencetakan uang, pemerintah sebagai penyelenggara negara mempunyai hak untuk mencetak uang. Pencetakan uang biasanya dilakukan untuk menutup defisit anggaran, ketika tidak ada cara lain untuk menutupnya. ${ }^{22}$ 


\section{Belanja Negara}

Belanja terdiri atas dua jenis, yaitu Belanja Pemerintah Pusat dan Belanja Daerah. Belanja Pemerintah Pusat, adalah belanja yang digunakan untuk membiayai kegiatan pembangunan Pemerintah Pusat, baik yang dilaksanakan di pusat maupun di daerah (dekonsentrasi dan tugas pembantuan). Belanja Pemerintah Pusat dapat dikelompokkan menjadi: Belanja Pegawai, Belanja Barang, Belanja Modal, Pembiayaan Bunga Utang, Subsidi BBM dan Subsidi Non-BBM, Belanja Hibah, Belanja Sosial (termasuk Penanggulangan Bencana), dan Belanja Lainnya. Belanja Daerah, adalah belanja yang dibagi-bagi ke Pemerintah Daerah, untuk kemudian masuk dalam pendapatan APBD daerah yang bersangkutan. Belanja Daerah meliputi: (1) Dana Bagi Hasil, (2) Dana alokasi Umum, (3) Dana Alokasi Khusus, dan (4) Dana otonomi khusus.

\section{Pembiayaan}

Pembiayaan meliputi dua bagian, yaitu (1) pembiayaan dalam negeri dan (2) pembiayaan luar Negeri. Pembiayaan Dalam Negeri meliputi Penggunaan saldo anggaran lebih (SAL) dan sisa lebih pembiayaan anggaran (SILPA). Pembiayaan Non-Perbankan meliputi: Privatisasi BUMN, Penjualan Aset Negara, Surat Utang Negara (SUN) atau Surat Berharga Negara (SBN). Pembiayaan Luar Negeri, meliputi: Penarikan Pinjaman Luar Negeri, terdiri atas Pinjaman Program dan Pinjaman Proyek. Pada bagian ini dimasukkan pula Pembayaran Cicilan Pokok Utang Luar Negeri, terdiri atas Jatuh Tempo dan Moratorium

\section{E. Analisis Fungsi Distribusi APBN Indonesia}

Tabel 1 menunjukkan bahwa kekayaan alam Indonesia ternyata tidak bisa signifikan menopang APBN Negara, baik dari minyak dan gas bumi, pertambangan umum, perikanan, maupun hasil hutan. Penerimaan sumber daya alam pun masih didominasi sektor migas. Hal ini menunjukkan sektor non-migas masih kurang perannya. Bagian laba BUMN hanya menyumbang 2,5 sampai 3 persen APBN, Penerimaan Negara bukan pajak lainnya mencapai 4,3 persen APBN, sedangkan pendapatan BLU mencapai 1-1,5 persen. Penerimaan utama negara tetap berasal dari sektor pajak, yaitu sebesar 75 persen. 
Tabel 1. Persentase APBN-P 2010 s.d. 2012.

\begin{tabular}{|c|r|r|r|}
\hline \multirow{2}{*}{ URAIAN } & \multicolumn{3}{|c|}{ Persentase APBN-P (\%) } \\
\cline { 2 - 4 } & $\mathbf{2 0 1 0}$ & $\mathbf{2 0 1 1}$ & $\mathbf{2 0 1 2}$ \\
\hline A. Pendapatan Negara dan Hibah & & & \\
I. Penerimaan Dalam Negeri & $\mathbf{9 9 , 8}$ & $\mathbf{9 9 , 6}$ & $\mathbf{9 9 , 9}$ \\
1. Penerimaan Perpajakan & $\mathbf{7 5 , 2}$ & $\mathbf{7 5 , 1}$ & $\mathbf{7 5 , 3}$ \\
a. Pajak Dalam Negeri & 72,9 & 71,1 & \\
b. Pajak Perdagangan Internasional & 2,4 & 4,0 & \\
2. Penerimaan Negara Bukan Pajak & $\mathbf{2 4 , 6}$ & $\mathbf{2 4 , 5}$ & $\mathbf{2 4 , 7}$ \\
a. Penerimaan Sumber Daya Alam & 16,5 & 16,4 & \\
1) SDA Migas & 15,3 & 14,8 & \\
2) Non Migas & 1,2 & 1,6 & \\
b. Bagian Laba BUMN & 2,9 & 2,5 & \\
c. PNBP Lainnya & 4,3 & 4,3 & \\
d. Pendapatan BLU & 1,0 & 1,3 & \\
II. Penerimaan Hibah & $\mathbf{0 , 2}$ & $\mathbf{0 , 4}$ & \\
\hline
\end{tabular}

Sumber: Nota Keuangan tahun 2010 s.d. 2012/data diolah.

Pembiayaan defisit APBN diklasifikasikan menjadi dua macam, yaitu pembiayaan non utang dan pembiayaan utang. Pembiayaan non utang berasal dari dua sumber, yaitu perbankan dalam negeri dan non perbankan dalam negeri. Tabel 2 menunjukkan bahwa sebagian besar defisit anggaran ditutup dengan pembiayaan utang, baik utang dalam negeri maupun utang luar negeri.

Tabel 2. Pembiayaan APBN tahun 2010 s.d. 2012

\begin{tabular}{|l|r|r|r|}
\hline \multirow{2}{*}{ URAIAN } & \multicolumn{3}{|c|}{ APBN-P (miliar rupiah) } \\
\cline { 2 - 4 } & $\mathbf{2 0 1 0}$ & $\mathbf{2 0 1 1}$ & \multicolumn{1}{c|}{$\mathbf{2 0 1 2}$} \\
\hline I. Pembiayaan Non-Utang & $23.041,4$ & $25.507,3$ & $33.943,1$ \\
a. Perbankan Dalam negeri & $45.477,1$ & $48.750,7$ & $60.561,6$ \\
b. Non Perbankan dalam negeri & $(22.435,7)$ & $(23.243,4)$ & $(26.618,5)$ \\
II. Pembiayaan Utang & $106.775,5$ & $125.329,4$ & $156.162,2$ \\
a. SBN (Neto) & $106.278,2$ & $126.653,9$ & $159.596,7$ \\
b. Pembiayaan Luar Negeri (neto) & $(502,6)$ & $(2.776,6)$ & $(4.425,7)$ \\
c. Pinjaman Dalam Negeri (Neto) & $1.000,0$ & $1.452,1$ & 991,2 \\
\hline jumlah & $\mathbf{1 2 9 . 8 1 6 , 9}$ & $\mathbf{1 5 0 . 8 3 6 , 7}$ & $\mathbf{1 9 0 . 1 0 5 , 3}$ \\
\hline
\end{tabular}

Sumber: Nota Keuangan tahun 2010 s.d. 2012/data diolah.

Melalui pola anggaran tahunan akan menunjukkan kinerja yang aman, sekalipun batasan defisit maksimal sudah diatur dalam Peraturan Pemerintah RI Nomor 23 tahun 2003. Keadaan ini perlu diperhatikan serius, karena 
kelemahan model akuntansi APBN maupun APBN-P dalam nota keuangan tidak dilengkapi dengan data seluruh utang yang ada. Terutama ketika terjadi pola pembayaran utang dilakukan dengan membuat utang baru yang lebih besar dan sifatnya jangka panjang.

Kondisi Indonesia dengan pola APBN tersebut, sulit untuk mencapai citacita Negara yang tertuang dalam UUD 1945. Hal ini karena beberapa alasan:

1. Pola anggaran defisit, yang kemudian ditutup dengan utang luar negeri yang selalu lebih besar dari tahun sebelumnya, akan menyebabkan Negara terjebak dalam lingkaran utang, sekalipun rasio utang terhadap sudah GNP menunjukkan perkembangan yang baik. Hal ini juga disebabkan karena sumber utama pemasukan negara berasal dari pajak yang meningkat dari tahun ke tahun.

2. Pemasukan Negara sebagian besar dari sektor pajak, dan tidak tampak upaya serius untuk menggali sumber lain seperti dari tiga sektor yang sangat potensial yaitu sektor kehutanan, perikanan, dan pertanianperkebunan. Pemasukan Negara dari sektor pajak sebenarnya menghambat tumbuhnya perekonomian. Sementara di sektor lain, yang mempunyai dua keuntungan yaitu meningkatnya pendapatan tanpa memperlambat laju ekonomi, sekaligus menggerakkan pertumbuhan ekonomi. Negara lebih suka mencari jalan yang mudah, yaitu menarik pajak dari rakyat, dan menghindari aktivitas yang sulit dan berat, yaitu memajukan sektor pemasukan Negara, baik melalui SDA maupun industri.

3. Pola pengeluaran Negara tidak mengarah pada kemandirian ekonomi, seperti penciptaan perusahaan Negara, baik berupa BUMN maupun sektor swasta yang kuat, yang bergerak baik di level hulu sampai hilir. Negara justru sedang menjalankan proses privatisasi, bahkan atas kepemilikan Negara, yang seharusnya dikelola oleh Negara untuk menghasilkan kemakmuran rakyat yang sebesar-besarnya.

4. Cara yang ditempuh untuk mengurangi defisit adalah dengan mengurangi ataupun mencabut subsidi, yang kemudian menyebabkan turunnya daya beli masyarakat. Cara lain yang tidak kalah berbahayanya adalah kebijakan mencetak uang, sekalipun legal namun akan meningkatkan inflasi. 
Berdasarkan empat hal tersebut, maka Negara Indonesia pada hakikatnya sedang dalam kondisi bahaya, jika tidak dilakukan upaya perbaikan sistemik. Bangsa Indonesia belum sepenuhnya merdeka, karena ternyata telah terjadi perubahan metode penjajahan, dari penjajahan langsung menuju penjajahan tidak langsung, yaitu melalui jebakan hutang (debt-trap).

Hal kedua yang perlu dicermati adalah Indonesia memacu pertumbuhannya tidak saja dari utang, melainkan dari arus investasi asing yang masuk ke Indonesia. Pemerintah menjadikan swasta sebagai lokomotif pembangunan dengan memberikan beban untuk menyerap 75 persen tenaga kerja. Sebagian besar investasi yang diperoleh dari utang luar negeri, bahkan ditempatkan pada dua jalur yang keliru, yaitu untuk investasi yang kurang produktif dan berjangka panjang, seperti sektor properti disamping sebagian besar revenue berupa rupiah, sehingga rentan terhadap perubahan nilai tukar mata uang. ${ }^{23}$

Pemerintah memberikan subsidi kepada rakyat berupa subsidi BBMBBN-LPG, subsidi listrik, subsidi pangan, subsidi pupuk, subsidi pajak, subsidi bunga kredit. Pada tahun 2011 menambahkan kewajiban pelayanan umum (public service obligation), serta tahun 2012 memberikan subsidi benih. Pemberian subsidi ini memang berpengaruh terhadap ekonomi rakyat, namun ternyata tidak mempunyai pengaruh langsung yang signifikan dalam rangka menghilangkan kemiskinan. Hal ini dibuktikan dengan masih tingginya angka kemiskinan di Indonesia, berdasarkan data dari BPS.

Konsekuensi dari solusi yang diambil pemerintah dalam upaya menutup defisit APBN tersebut adalah sebagai berikut: (1) pencabutan subsidi akan menyulitkan rakyat kecil, (2) menaikkan pajak akan menghambat pertumbuhan ekonomi, sedangkan (3) melalui utang perlu pertimbangan yang matang, terkait dengan dua hal, aspek teologis yaitu riba hukumnya haram dalam Islam, serta aspek ekonomis, bahwa beban utang akan memperberat APBN pada tahuntahun berikutnya.

23 Agus Muhammad, "Pengawasan Pengelolaan Keuangan Negara dari orde baru ke reformasi", dalam Anggito Abimanyu dan Andie Megantara (Ed.) Era Baru Kebijakan Fiskal, (Jakarta: Penerbit Buku Kompas, 2009), hal. 582-584. 


\section{F. Analisis Politik Ekonomi Islam dan Prognosis APBN Baitul Mal}

Kesulitan utama perencanaan anggaran negara terletak pada pengalokasian sumber daya ke dalam berbagai program kebijakan pengeluaran negara. Sasaran kebijakan negara yang penting untuk dipenuhi jumlahnya banyak serta terdapat skala prioritas tertentu yang harus dipertimbangkan, harus berhadapan dengan realitas keterbatasan sumber daya untuk membiayai pencapaian sasaransasaran tersebut. Jadi, diperlukan desain sistem kebijakan pengeluaran negara yang baik dalam rangka menyelesaikan kesulitan tersebut.

Sebuah keharusan bagi negeri-negeri Islam untuk merancang politik ekonominya sendiri berdasarkan pemikiran komprehensif yang dianutnya, yaitu aqidah Islam. Kebijakan ekonomi negeri-negeri Islam harus berupa hukum-hukum syara' yang digali dari al-Qur'an dan as-Sunnah, atau dalil-dalil yang ditunjukkan oleh kedua dalil utama tersebut. Politik ekonomi inilah yang akan menentukan skala prioritas pengeluaran negara. Politik Ekonomi adalah target yang menjadi sasaran hukum-hukum yang menangani pengaturan

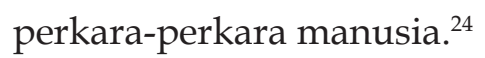

Politik Ekonomi Islam adalah jaminan terpenuhinya pemuasan semua kebutuhan pokok (primer) tiap-tiap individu dan memenuhi kebutuhankebutuhan pelengkap (sekunder dan tersier) sesuai kadar kemampuannya sebagai individu yang hidup dalam masyarakat tertentu, yang memiliki gaya hidup yang khas, yaitu Islam. ${ }^{25}$ Politik ekonomi Islam tidak sekedar meningkatkan taraf hidup dalam sebuah negara semata atau terwujudnya keadilan sosial. Politik ekonomi Islam tidak menjadikan pertumbuhan pendapatan nasional sebagai asasnya, dan tidak pula memperbanyak barang dan jasa yang menjamin terwujudnya kemakmuran hidup manusia, kemudian membebaskannya untuk mendapatkannya sesuai dengan kemampuannya dengan cara memberikan kebebasan memiliki dan bekerja. ${ }^{26}$ Inilah perbedaan mendasar antara politik ekonomi Islam dengan politik ekonomi Kapitalisme.

Berdasarkan konsep dasar politik ekonomi Islam tersebut, perlu memperhatikan dua hal, yaitu: (1) pembahasan tentang sumber-sumber

24 Abdurrahman al-Maliki, Politik Ekonomi Islam (as-Siyasatu al-Iqtishadiyatu al-Mutsla), alih bahasa oleh Ibnu Sholah, (Bangil: al-Izzah, 2001), hal. 36-37.

25 Taqyudin an-Nabhani, Membangun., hal., 52.

26 Abdurrahman al-Maliki, Politik., hal. 38. 
ekonomi dan (2) jaminan terpenuhinya kebutuhan-kebutuhan primer bagi setiap individu warga negara dan kebolehan untuk memenuhi kebutuhan pelengkapnya sesuai kemampuannya masing-masing. ${ }^{27}$

Pembahasan pertama terkait politik ekonomi Islam adalah sumber-sumber ekonomi utama. Sumber-sumber ekonomi yang utama ada empat, yaitu pertanian, perindustrian, perdagangan, dan tenaga manusia (jasa), sedangkan pendapatan yang lain, seperti pariwisata dan transportasi dikategorikan sebagai sumber ekonomi sekunder atau pelengkap. ${ }^{28}$ Fokus utama negara seharusnya pada pengembangan empat sumber ekonomi primer, karena sifatnya yang strategis, jika negara benar-benar menginginkan dirinya menjadi kuat dan mandiri. Jadi, langkah strategis negara dalam mewujudkan kesejahteraan rakyat adalah: (1) peningkatan produksi pertanian (politik pertanian), (2) membangun industri dasar (politik perindustrian), (3) pengembangan perdagangan luar negeri (politik perdagangan), dan (4) peningkatan kualitas sumber daya manusia.

Pertanian perlu diperhatikan pertama kali karena kebutuhan utama manusia adalah pangan. Produksi pertanian yang ditingkatkan terdiri atas tiga macam, yaitu: (1) bahan makanan, (2) bahan pakaian, dan (3) komoditi yang bernilai di pasar luar negeri. ${ }^{29}$ Peningkatan produksi bahan makanan diarahkan untuk memenuhi kebutuhan bahan pangan dalam negeri serta mempunyai cadangan untuk kondisi darurat. Negara dalam hal ini tidak akan melakukan impor bahan pangan ataupun alat-alat pertanian. Peningkatan produksi bahan pakaian seperti kapas (cotton), wool, serat rami, dan serat sutra juga dilakukan karena pakaian merupakan kebutuhan pokok individual, sebagaimana pangan. Negara juga tidak akan melakukan import bahan pakaian maupun pakaian. Komoditi yang punya pasar luar negeri, baik berupa makanan seperti buahbuahan, coklat, kopi, teh, ataupun pakaian seperti kapas, wool, dan sutra, ataupun komoditas lain seperti karet dan minyak sawit/minyak kelapa, akan ditingkatkan produksinya dengan orientasi ekspor. Hal ini karena negara tidak akan mampu melakukan ekspor terhadap hasil industri pada tahap awal ini. Inilah yang dimaksud dengan politik pertanian.

\footnotetext{
27 Ibid., hal. 39.

28 Ibid., hal. 41.

29 Abdurahman al-Maliki, Politik., hal 195-199.
} 
Perindustrian merupakan aspek paling penting bagi umat, bangsa, atau pun masyarakat manapun. Kemajuan bagian perindustrian akan memudahkan kehidupan manusia, baik industri manual maupun mesin (mekanis). Hukum asal industri adalah kepemilikan individu, sehingga setiap warga negara boleh memiliki industri. ${ }^{30}$ Hanya saja industri yang memroduksi barang-barang yang termasuk kepemilikan umum, tidak boleh dimiliki pribadi. Barangbarang yang termasuk kepemilikan umum meliputi: (1) barang tambang yang jumlah depositnya besar, (2) sumber daya alam yang sifat pembentukannya menghalangi untuk dimiliki individu/perorangan, dan (3) harta benda yang termasuk fasilitas umum. ${ }^{31}$

Perhatian utama negara terkait sektor industri adalah melakukan transformasi menjadi negara industri secara langsung, bukan melakukan revolusi pertanian terlebih dahulu, sebagai persiapan sebagai negara industri ataupun melakukan eksploitasi barang tambang. Target utama negara adalah menjadi negara industri, dengan melakukan revolusi industri, yaitu membangun industri yang menghasilkan mesin-mesin untuk membuat mesin (industri dasar). Politik industri dilakukan oleh negara tanpa memandang keuntungan ataupun kerugian sesaat, karena ada tujuan jangka panjang yang harus dicapai. Impor hanya bisa dilakukan terkait dengan produksi mesin pembuat mesin atau komoditas-komoditas untuk membuat mesin dasar tersebut. Keberadaan mesin pembuat mesin, akan memungkinkan negara membangun sektor perindustrian dengan mandiri.

Pembangunan ini hanya bisa dilakukan melalui alat yang diproduksi dalam negeri, tidak boleh melakukan impor. Kebijakan ini sekaligus akan membuka pasar bagi industri yang sudah ada, yaitu industri peralatan. Satu hal yang perlu dipertimbangkan adalah kualitas produk. Kualitas produksi harus menjadi perhatian utama, karena jika dibuat dengan standar kualitas kedua atau lebih rendah, maka kebijakan yang digariskan tersebut akan menjadi tidak bisa diimplementasikan dengan mulus di lapangan. Negara perlu melakukan dua hal agar industri peralatan segera terealisasi, yaitu: (1) mengundang ratusan atau bahkan ribuan SDM (insinyur dan ahli/ pekerja teknik) dari negara industri maju untuk bekerja dan mengembangkan industri mesin pembuat mesin dan

\footnotetext{
$30 \quad$ Ibid., hal. 74.

31 Ibid., hal. 79.
} 
(2) mengirimkan ribuan mahasiswa dan pelajar untuk belajar teknologi ke luar negeri. Melalui dua langkah ini, maka industri mesin pembuat mesin dapat segera beroperasi, dan ketika negara melakukan pembangunan industri, tenaga kerja bisa dicukupi yaitu dengan kembalinya ribuan insinyur dan ahli/pekerja teknik.

Pembangunan industri tetap harus difokuskan untuk produksi hal-hal yang sangat dibutuhkan negara, seperti pembuatan mesin-mesin dan persenjataan. Hal ini untuk mengurangi ketergantungan terhadap negara lain. ${ }^{32}$ Industri konsumtif seperti industri tekstil dan kertas belum menjadi prioritas negara. Hal ini tidak berarti bahwa industri yang sudah ada dihentikan produksinya. Negara hanya tidak memprioritaskannya dalam pembangunan, sehingga anggaran belanja negara tidak akan digunakan untuk membangunnya. Industri-industri yang ada di Indonesia, sebagian besar berupa industri tekstil (pemintalan, penenunan, dan garmen), industri gula dan makanan kemasan, industri pengolahan kayu, industri semen, industri pupuk, dan sisanya adalah industri yang sifatnya konsumtif.

Kebijakan pengelolaansumber dayaalam sama dengan pengelolaan industri. Negara tidak akan mengembangkan pertambangan pada tahap ini, sehingga tidak akan mengeksplorasi tambang-tambang baru, menambah tambang baru, ataupun membeli peralatan baru untuk peningkatan produksi ataupun efisiensi. Negara juga tidak akan mengundang investasi asing maupun dalam negeri untuk masuk dalam pengelolaannya, karena sumber daya alam merupakan kepemilikan umum. Pertambangan yang sudah ada tetap dijalankan, yaitu setelah melalui perubahan kontrak kerja. Pengembangan sektor pertambangan hanya akan dilakukan ketika negara telah mampu membuat mesin-mesinnya sendiri.

Sektor ketiga adalah perdagangan. Perdagangan adalah aktivitas jual beli, yaitu barter barang dengan barang, baik dalam negeri maupun luar negeri. ${ }^{33}$ Fokusnya adalah menerapkan hukum syara' tentang perdagangan. Jadi sebagaimana politik pertanian, negara tidak melakukan campur tangan

32 Pembangunan industri yang mandiri dan kuat merupakan salah satu langkah yang bisa digunakan untuk mematahkan embargo dari negara lain, baik embargo ekonomi, politik, maupun intelektual. Embargo adalah salah satu upaya untuk memaksakan kehendak suatu negara kuat kepada negara lain yang lebih lemah.

33 Abdurrahman al-Maliki, Politik., hal. 101. 
terhadap aktivitas ini. Politik perdagangan diserahkan kepada rakyat. Negara tidak akan banyak campur tangan dalam hal ini, kecuali menjaga agar transaksi berjalan sesuai dengan hukum syariat. Negara hanya akan menggunakan infrastruktur yang ada dalam masalah perdagangan ini, dan tidak akan membangun infrastruktur baru. Negara akan memfokuskan perhatiannya pada pembangunan pasar luar negeri dalam rangka mendapatkan mata uang keras (hard money) yang akan digunakan untuk membeli peralatan yang diperlukan bagi revolusi industri atau komoditas-komoditas yang diperlukan dalam revolusi tersebut.

Tiga sumber ekonomi, yaitu pertanian, perindustrian, dan perdagangan, memerlukan bantuan tenaga kerja manusia dalam produksi. Tenaga manusia adalah aktivitas yang dilakukan manusia, baik berhubungan dengan akal maupun fisik. Politik ketenagakerjaan ditopang oleh politik pendidikan. Negara harus menjamin penuh peluang rakyat untuk mendapatkan pendidikan, dengan biaya yang ditanggung oleh negara. Negara, di sisi lain juga harus memberikan jaminan kesehatan kepada rakyatnya, sehingga jumlah ketersediaan tenaga kerja akan mencukupi kebutuhan. Hal ini akan dibahas pada bagian kedua dari politik ekonomi Islam.

Bagian kedua yang perlu diperhatikan dalam politik ekonomi Islam adalah jaminan pemenuhan kebutuhan pokok (primer) setiap individu warga negara, dan kebolehan untuk memenuhi kebutuhan pelengkapnya sesuai kemampuan masing-masing. Jadi fokus utama politik ekonomi Islam terkait distribusi ekonomi ada dua, yaitu terpenuhinya kebutuhan pokok (primer) bagi semua individu warga negaranya, yaitu untuk fakir dan miskin, orangorang yang lemah secara fisik, dan pengangguran, serta pihak-pihak yang membutuhkannya.

Hal pertama yang diperhatikan adalah pemenuhan kebutuhan primer individual. Targetnya adalah angka kemiskinan menjadi nol (nihil) karena adanya program untuk menghilangkannya, bukan sekedar menurunkan angka kemiskinan yang dalam hal ini negara hanya memfasilitasi melalui serangkaian regulasi, di mana pemenuhannya semuanya diserahkan pada kemampuan masing-masing individu, dan tidak ada jaminan nyata dari sistem. Ukuran tersebut berupa tidak adanya lagi nama warga negara di dalam daftar penerima zakat dari golongan fakir-miskin. 
Beban negara, terkait dengan santunan kepada rakyatnya yang tidak mampu dalam rangka mewujudkan nihilnya angka kemiskinan, akan berkurang dari tahun ke tahun, yaitu ketika negara mampu menciptakan lapangan pekerjaan. Lapangan pekerjaan yang dimaksud bukan dengan membuat proyek-proyek padat karya untuk pembangunan infrastruktur, karena keuangan negara harus difokuskan untuk transformasi menuju negara industri. Lapangan pekerjaan yang dimaksud adalah pengembangan dua sumber ekonomi, yaitu pertanian dan perdagangan. Dua sektor ini cukup sederhana sehingga negara tidak perlu banyak campur tangan atau dengan kata lain negara cukup mendorong individu warga negaranya untuk berproduksi, bekerja, dan berdagang, dengan memberikan fasilitas sesuai kadar kemampuan negara dalam dua sektor tersebut.

Negara selain mempunyai kewajiban memenuhi kebutuhan pokok individual rakyatnya (pangan, sandang, dan tempat tinggal), juga mempunyai kewajiban memenuhi kebutuhan pokok kolektif masyarakat. ${ }^{34}$ Kebutuhan kolektif masyarakat, berupa jaminan keamanan, layanan kesehatan, dan layanan pendidikan. Jaminan pemenuhan kebutuhan kolektif masyarakat ini akan berdampak terhadap kualitas tenaga kerja manusia, yang merupakan salah satu sumber ekonomi. Jaminan keamanan dan kesehatan memberikan ketenangan setiap warga negara serta menjamin adanya tenaga kerja yang siap berproduksi, sedangkan pendidikan akan mempengaruhi tingkat produktifitasnya. Inilah yang diperlukan dalam program pembangunan negara dalam mewujudkan kesejahteraan rakyat. Inilah politik ekonomi Islam yang merupakan garis-garis besar pembangunan, acuan penyusunan anggaran belanja negara.

Prinsip dasar penyusunan Baitul Mal berbeda dengan konsep APBN sistem kapitalisme. Sumber-sumber penerimaan Baitul Mal sama sekali tidak mengandalkan dari pajak, dan sebisa mungkin menghindari memungut pajak dari rakyat. Pajak hanya dipungut jika kas Baitul Mal dalam kondisi kosong. Pungutan pajak dibebankan pada individu yang mampu saja, dan tidak dipungut atas perusahaan.

Sebagaimana dijelaskan pada bab Baitul Mal, sumber-sumber pendapatan dari Baitul Mal sudah ditentukan oleh syariat, yaitu dari sektor kepemilikan

34 Jika negara mampu memenuhi kebutuhan pokok rakyatnya, baik yang sifatnya individual maupun kolektif, maka negara akan stabil. 
individu, kepemilikan umum dan kepemilikan negara. Ketentuan belanja dalam Baitul Mal berbeda dengan yang dianut oleh sistem kapitalisme. Khalifah sebagai seorang kepala negara dalam sistem ekonomi Islam mempunyai kewenangan penuh untuk menetapkan anggaran belanjanya tanpa harus menunggu persetujuan Majelis umat atau saat ini dikenal sebagai DPR.

Khalifah juga tidak terikat dengan tahun fiskal dalam menyusun anggaran Baitul Mal. Khalifah dalam menjalankan dan menetapkan anggaran belanjannya hanya tunduk dan taat dengan kaidah-kaidah yang telah ditetapkan oleh hukum syariat Islam. Khalifah memiliki kewenangan penuh untuk mengatur pos-pos pengeluaran, dan juga berapa dana yang harus dialokasikan, dengan mengacu pada kemaslahatan dan keadilan bagi seluruh rakyatnya. Kewenangan khalifah tersebut berdasarkan pada ketentuan syariat Islam, sebagaimana yang digariskan oleh Allah SWT dalam Al-Qur'an..$^{35}$

Kaidah-kaidah pengeluaran kas Baitul Mal dapat disederhanakan menjadi enam, yaitu:

1. Harta zakat akan dipisahkan pengelolaannya. Harta ini hanya dibelanjakan untuk delapan golongan jika memang kas-nya terisi, sehingga bila zakat habis, maka tidak ada seorang pun dari delapan golongan penerima zakat berhak mendapatkannya, dan negara tidak akan menarik pajak atau mencari pinjaman.

2. Pembelanjaan yang bersifat wajib, seperti santunan kepada fakir miskin, atau untuk melakukan jihad, maka negara harus menyediakannya karena dikhawatirkan akan terjadi kerusakan jika tidak tersedia, sehingga negara dapat meminjam harta dan setelah itu dilunasi, atau dapat pula menarik pajak.

3. Pembelanjaan yang sifatnya kompensasi, yakni bagi orang-orang yang telah memberikan jasa, seperti tentara, pegawai negeri, qadli, guru, maka sifatnya juga wajib.

4. Pembelanjaan karena unsur keterpaksaan, seperti bencana alam atau serangan musuh, maka sifatnya juga wajib.

5. Pembelanjaan untuk suatu kemaslahatan, bukan termasuk kompensasi, namun sifatnya penting (vital), yang jika tidak ada maka masyarakat akan kesulitan, seperti infrastruktur penting, maka sifatnya juga wajib. 
6. Pembelanjaan untuk suatu kemaslahatan, hanya saja bila tidak ada maka umat tidak akan menderita, seperti pembangunan infrastruktur sekunder, maka akan dianggarkan jika terdapat dana di baitul Mal, namun jika tidak ada maka akan ditunda sampai ada dana atau tidak disetujui.

Jika melihat skala prioritas maka ada dua hal yang perlu diperhatikan, yaitu: (1) Pengeluaran yang utama dalam kas baitul mal adalah untuk pemenuhan kebutuhan pokok individu. Di dalam sistem ekonomi Islam kebutuhan pokok individu dijamin oleh Negara. Adapun kebutuhan pokok tersebut terdiri dari: pangan, sandang, dan papan, pendidikan, kesehatan, dan keamanan. ${ }^{36}$ (2) Selain untuk memenuhi kebutuhan pokok individu, kas baitul mal juga digunakan untuk keperluan-keperluan lain yang bertujuan untuk memenuhi kemaslahatan umum, seperti pembangunan sarana dan prasarana umum, seperti: perumahan, jalan raya, tempat ibadah, jembatan, pasar, terminal, rel kereta api. Pembangunan ini adalah tanggung jawab penuh negara dan tidak dibebankan kepada rakyat. Pembangunan industri berat seperti pembangunan industri militer dan industri strategis lainnya, sesuai dengan garis besar politik industri.

Prognosis ini diajukan, sekalipun perhitungan masih sangat kasar, untuk menunjukkan bahwa ketika negara menjalankan kebijakan ekonomi yang tepat, maka gambaran masa depan gemilang akan nampak. Gambaran masa depan suram justru yang muncul ketika mencermati APBN Indonesia dari tahun 2010-2012, yang mana cenderung defisit dari tahun ke tahun dengan solusi utama adalah mengandalkan pendapatan berupa pajak serta melalui utang untuk menutupnya, sedangkan disisi lain program-program pemerintah bersifat sektoral dan kadang tumpang tindih sehingga menghasilkan inefisiensi anggaran.

Penerapan konsep keuangan negara menurut Abdul Qadim Zallum ini menjanjikan suasana baru. Perombakan birokrasi akan dilakukan dengan tujuan untuk menyederhanakan birokrasi dan mempercepat layanan kepada

36 Ukuran keberhasilan ekonomi Islam berbeda dengan sistem ekonomi Kapitalisme yang menggunakan pertumbuhan ekonomi sebagai indikatornya. Ukuran keberhasilan dan kesejahteraan suatu Negara dalam ekonomi Islam adalah ketika setiap penduduk bisa mendapatkan atau terpenuhi kebutuhan pokoknya. Jika masih ada satu orang saja yang tidak terpenuhi kebutuhan pokoknya, maka negara tersebut belum layak dikatakan sejahtera 
masyarakat. Pemerintah harus fokus pada tugas-tugasnya. Rekapitulasi Anggaran belanja Negara dapat dilihat pada tabel 3.

Tabel 3. Prognosis Rekapitulasi Anggaran Belanja Negara

\begin{tabular}{|l|l|l|}
\hline \multicolumn{1}{|c|}{ Belanja Negara } & \multicolumn{1}{|c|}{ Dinar } & \multicolumn{1}{c|}{ miliar Rupiah } \\
\hline Pengeluaran Pusat & 9.984 & 21,216 \\
\hline 1. Kantor Khalifah & 1.920 & 4,08 \\
\hline 2. Kantor Penasehat & 4.080 & 8,67 \\
\hline 3. Kantor Mu'awin at-Tafwid & 1.824 & 3.876 \\
\hline 4. kantor $M u^{\prime}$ awin at-Tanfiz & 2.160 & 4,59 \\
\hline Mashalih Daulah & 444.423 .513 & 944.400 \\
\hline 1. Departemen Perang & 35.760 .000 & 75.990 \\
\hline 2. Departemen luar Negeri & 2.728 .000 & 5.797 \\
\hline 3. Pemerintah Daerah & 25.933 .152 & 55.107 .948 \\
\hline 4. Peradilan & 10.428 .120 & 22.159 .755 \\
\hline 5. Pelayanan Publik & 290.241 .960 & 616.764 .165 \\
\hline a. Kesehatan & 77.237 .568 & 164.129 .832 \\
\hline b. Pendidikan dan Dakwah & 192.004 .392 & 408.009 .333 \\
\hline c. Keamanan & 21.000 .000 & 44.625 \\
\hline 6. Badan-badan/lembaga lain & 81.923 .481 & 174.087 \\
\hline 7. Majelis Umat \& Wilayah & 136.800 & 290,7 \\
\hline Santunan & 172.941 .176 & 367.500 \\
\hline Jihad & 23.860 .000 & $50.702,5$ \\
\hline 1. Pasukan & 8.940 .000 & $18.997,5$ \\
\hline 2. Persenjataan & 4.920 .000 & 10.455 \\
\hline 3. Industri Militer & 10.000 .000 & 21.250 \\
\hline Penyimpanan Harta Zakat & 0 & 0 \\
\hline Penyimpanan Harta Milik Umum & 0 & 0 \\
\hline Dana Darurat & 1.000 .000 & 2.125 \\
\hline Anggaran Belanja Negara & 42.480 & 90,27 \\
\hline Jumlah Pengeluaran Total & 642.277 .153 & $1.364 .838,951$ \\
\hline & & \\
\hline
\end{tabular}

Berdasarkan pengeluaran negara, kemudian disusunlah anggaran pemasukan negara. Polanya adalah semua pengeluaran yang sifatnya wajib, maka harus dipenuhi termasuk dengan jalan menarik pajak (daribah) maupun melalui utang tanpa riba, sedangkan yang sifatnya bisa ditunda, maka ditunda terlebih dahulu, jika tidak tersedia anggarannya. Tabel 4 menunjukkan estimasi pemasukan negara. 
Tabel 4. Prognosis Rekapitulasi Anggaran Pemasukan Negara

\begin{tabular}{|l|r|r|}
\hline \multicolumn{1}{|c|}{ Pemasukan Negara } & Dinar & miliar Rupiah \\
\hline A. Kepemilikan Negara & 286.843 .550 & 609.543 \\
\hline 1. Pajak & 261.108 .750 & 554.856 \\
\hline 2. Jizyah & 25.734 .800 & 54.686 \\
\hline B. Kepemilikan Umum & 359.227 .118 & 763.358 \\
\hline 1. Kehutanan & 235.294 .118 & 500.000 \\
\hline 2. Kelautan & 70.000 & 149 \\
\hline 3. Pertambangan panas Bumi & 163.000 & 346 \\
\hline 4. Minyak Bumi & 70.000 .000 & 148.750 \\
\hline 5. Gas Alam & 18.600 .000 & 39.525 \\
\hline 6. Pertambangan Umum & 23.500 .000 & 49.938 \\
\hline 7. Laba BUMN & 11.600 .000 & 24.650 \\
\hline C. Zakat dan Shadaqah & 0 & 0 \\
\hline Jumlah Pemasukan Total & 646.070 .668 & 1.372 .900 \\
\hline
\end{tabular}

Prognosa ini menunjukkan bahwa jaminan kebutuhan pokok kepada rakyat, individu per inidividu sebesar Rp 367 triliun, serta jaminan kesehatan, pendidikan, keamanan penuh dari negara, mampu dilakukan oleh negara. Kebijakan fiskal ini akan menggerakkan roda perekonomian rakyat, terutama di tingkat bawah. Gelontoran dana ini akan menggiatkan sektor perdagangan, karena meningkatnya daya beli masyarakat. Imbasnya adalah majunya sektor perdagangan. Sektor perdagangan ini akan menarik sektor produktif lainnya, terutama sektor pertanian (termasuk peternakan) dan kelautan-perikanan.

Percepatan perputaran ekonomi di tingkat bawah ini akan meningkatkan kesejahteraan rakyat secara simultan. Stimulus inilah yang akan melancarkan sekrup-sekrup dalam mesin ekonomi. Uang juga tetap berada di jalur normal, karena tertutupnya pintu-pintu kemaksiatan. Fokus pengelolaan keuangan negara adalah mencermati hal-hal yang penting, memprioritaskannya, untuk kemudian melompat ke tingkat kemakmuran yang lebih tinggi.

\section{G. Penutup}

Berdasarkan paparan di atas, ada beberapa poin utama yang bisa menjadi bahan pertimbangan, yaitu:

1. Fokus fungsi distribusi APBN menurut Syaikh Abdul Qadim Zallum terkait dengan politik ekonomi negara. Prinsip dasarnya adalah 
negara harus menjamin kebutuhan pokok rakyat, sebagai individu per individu dan bukan melihat kebutuhan masyarakat keseluruhan, serta memberikan kesempatan seluas-luasnya kepada warga negara untuk memenuhi kebutuhan pelengkapnya. Kebutuhan pokok rakyat meliputi kebutuhan personal yaitu pangan, pakaian, dan tempat tinggal, serta kebutuhan yang sifatnya komunal, yaitu keamanan, kesehatan, dan pendidikan. Ini semua merupakan tanggung jawab negara.

2. APBN merupakan wewenang dan tanggung jawab negara, namun dalam penentuannya harus terikat dengan hukum syariat baik dalam aspek pemasukan maupun pengeluaran. Pemimpin negara dalam penyusunan anggaran akan dibantu oleh badan perencana anggaran negara, sedangkan dalam pelaksanaannya akan dibantu oleh Baitul Mal.

3. Negara Indonesia pada hakikatnya sedang dalam kondisi bahaya, karena terancam terperangkap dalam penjajahan tidak langsung, yaitu melalui jebakan utang (debt-trap), jika tidak dilakukan upaya perbaikan sistemik. Defisit anggaran semakin besar dari tahun ke tahun tersebut ditutup dengan pembiayaan yang sebagian besar berupa utang. Hal ini diperparah dengan ketidak-tepatan program karena mengikuti arahan pihak asing (IMF dan World Bank), perputaran ekonomi terjadi di kalangan terbatas, inefisiensi anggaran melalui praktek mark-up proyek, korupsi, atau suap. Di sisi lain pemasukan utama negara adalah pajak yang tentunya kan memperberat rakyat serta memperlambat laju ekonomi. Upaya untuk mensejahterakan rakyat melalui upaya pemberian santunan/subsidi juga setengah hati dilakukan pemerintah, padahal jika dilakukan akan memperlancar putaran ekonomi di kalangan bawah.

4. Penerapan keuangan Islam pemikiran Syaikh Abdul Qadim Zallum secara garis besar mampu memenuhi kewajiban pemerintah, baik santunan kebutuhan pokok rakyat, gaji dan santunan untuk pegawai negeri dan penguasa, menjalankan proses pemerintahan, serta yang paling penting menggulirkan proyek industrialisasi. Santunan kebutuhan pokok dan jaminan kebutuhan pokok kolektif mencapai 72,1 
persen dari total APBN sebesar 642.277.153 Dinar (setara dengan Rp 984.264 miliar dari total APBN sebesar Rp 1.364.838,951 miliar). Sebagai perbandingan, anggaran militer hanya mencapai 9,2 persen. Sisanya digunakan untuk menjalankan proses pemerintahan, membangun infrastruktur, serta menjalankan politik industri.

Pendapatan negara masih mengandalkan pajak pada tahap awal, namun pemasukan ini akan berkurang drastis seiring dengan berkurangnya penduduk miskin, sehingga akan mempercepat peningkatan kemakmuran bersama. Pendapatan pajak mencapai 40 persen dari pendapatan negara, inijauh lebih kecil dibandingkan dengan pendapatan APBN Indonesia yang didominasi sektor pajak, yang mencapai 75 persen. Pendapatan dari pajak kemudian dikembalikan kepada masyarakat dalam bentuk santunan kebutuhan pokok rakyat (pangan, pakaian, dan tempat tinggal) yang diberikan kepada penduduk yang miskin, serta kebutuhan pokok kolektif masyarakat (keamanan, kesehatan, dan pendidikan) yang diberikan kepada seluruh penduduk. Hal inilah yang akan membuat kondisi negara menjadi stabil, sehingga ekonomi akan bergerak maju.

\section{DAFTAR PUSTAKA}

Dodiman, M 'Ali. 2012. Memoar Pejuang Syari'ah dan Khilafah, Biografi Ringkas Tokoh Senior Hizbut Tahrir. Bogor: al-Azhar Freshzone publishing.

Hamid, Edy Suandi. 2004. Sistem Ekonomi, Utang Luar Negeri, dan Isu-isu Ekonomi Politik Indonesia. Yogyakarta: UII Press. .2006. Ekonomi Indonesia, dari Sentralisasi ke Desentralisasi. Yogyakarta: UII Press.

Hizbut Tahrir. 2006. Struktur Negara Khilafah (Pemerintahan dan Administrasi); Terjemahan oleh Yahya Abdurrahman, dari Ajhizah Daulah al-Khilafah (2005). Jakarta: HTI-Press.

Maliki, Abdurrahman. 2001. Politik Ekonomi Islam; Terjemahan oleh Ibnu Sholah, dari As-Siyasatu al-Iqtishadiyatu al-Mutsla. Bangil: Al-Izzah.

Muhammad, Agus. 2009. “Pengawasan Pengelolaan Keuangan Negara dari orde baru ke reformasi", dalam Anggito Abimanyu dan Andie Megantara 
(Ed.) Era Baru Kebijakan Fiskal, Jakarta: Penerbit Buku Kompas.

Nabhani, Taqyuddin. 2002. Membangun Sistem Ekonomi Alternatif Perspektif Islam; Terjemahan oleh Maghfur Wachid, dari An-Nidlamu al-Iqtishadi fi al-Islam; edisi mu'tamadah (1990). Surabaya: Risalah Gusti

Republik Indonesia. 2003, Undang-Undang Republik Indonesia Nomor 17 Tahun 2003 tentang Keuangan Negara.

. 2010. Nota Keuangan dan Anggaran Pendapatan dan Belanja Negara Perubahan Tahun Anggaran 2010.

. 2011. Nota Keuangan dan Anggaran Pendapatan dan Belanja Negara Perubahan Tahun Anggaran 2011.

. 2012. Nota Keuangan dan Anggaran Pendapatan dan Belanja Negara Perubahan Tahun Anggaran 2012.

Suparmoko, 2003. Keuangan Negara dalam Teori dan Praktek, Edisi V, cetakan kedua, Yogyakarta: BPFE.

Triono, Dwi Condro, 2011. Ekonomi Islam Madzhab Hamfara, Jilid I. Yogyakarta: Irtikaz.

Waluyanto, Rahmat, 2009. Pengelolaan Utang Pemerintah (Surat Utang Negara, Surat Berharga Syariah Negara, dan Pinjaman Luar Negeri), dalam Anggito Abimanyu dan Andie Megantara (Ed.) Era Baru Kebijakan Fiskal, Jakarta: Penerbit Buku Kompas.

Yuswar Zainul basri dan Mulyadi Subri,2013. Keuangan Negara dan Analisis Kebijakan Utang Luar Negeri, Jakarta: Rajagrafindo Persada.

Yulianto. 2010. “APBN Anti Rakyat". Dalam al-Wa'ie, XI (122): 9. Jakarta.

Zallum, Abdul Qadim. 2002. Sistem Keuangan di Negara Khilafah; Terjemahan oleh Ahmad S, dari Al-Amwal fi ad-Daulah al-Khilafah; edisi mu'tamadah (1988). Bogor: Pustaka Thariqul Izzah. 